Ann. Biol. anim. Bioch. Biophys., 1979, 19 (4 A), 1147-1152.

\title{
Feedback regulation of pancreatic secretion in the young milk-fed calf
}

\author{
par Marie-Jeanne DAVICCO, J. LEFAIVRE *, P. THIVEND *, J. P. BARLET \\ with the technical assistance of R. DABERT, Bernadette LASSALAS *, R. ROUX \\ Laboratoire des Maladies Métaboliques \\ * Laboratoire de la Digestion des Ruminants \\ I.N.R.A., Theix, St-Genès-Champanelle, 63110 Beaumont.
}

Summary. Five male Holstein $\times$ Frisian calves, fed a milk replacer and weighing $85 \pm 2 \mathrm{~kg}$ when 45 days old, were fitted with a reentrant catheter (placed permanently at 10 days of age) on the pancreatic duct in order to study the effect of reintroducing pancreatic juice (or other solutions) into the duodenum on exocrine pancreatic secretion. When pancreatic juice was returned at the same rate as when it was collected during the preceding 15-minute period, mineral $(\mathrm{Ca}, \mathrm{Mg}, \mathrm{P}, \mathrm{Zn})$ and amylase pancreatic secretion decreased significantly $(-60 \pm 10$ p. 100) during the next $45 \mathrm{~min}$. When an aqueous $0.9 \mathrm{p} .100 \mathrm{NaCl}$ solution was introduced after pancreatic juice infusion, excretion of calcium $(+30 \pm 10 \mathrm{p}$. $100)$, proteins $(+100 \pm 20$ p. 100) and amylase $(+100 \pm 25$ p. 100) increased significantly $(+100+30$ p. 100). When physiological serum was replaced by a solution of bovine trypsin $\left(1.5 \mathrm{mg} \cdot \mathrm{ml}^{-1}\right.$ in $\left.0.9 \mathrm{p} .100 \mathrm{NaCl}\right)$ the excretion of water, minerals (- $\left.50 \pm 10 \mathrm{p} .100\right)$, proteins $(-80 \pm 5$ p. 100) and amylase $(-70 \pm 15$ p. 100) was significantly inhibifed. Adding a trypsin inhibitor, SBTI (1 mg SBTI inhibits $1.7 \mathrm{mg}$ of trypsin), to the trypsin solution infused, significantly stimulated $(+30 \pm 10$ p. 100) pancreatic secretion.

It is classically admitted that regulation of the secretionf rom the exocrine pancreas is controlled by nervous and hormonal mechanisms (Thomas, 1967 ; Harper, 1972).

However, previous studies have shown that pancreatic enzyme secretion in rats is controlled by a negative feed-back mechanism (Green and Lyman, 1972 ; Green ef al., 1973 ; Schneeman and Lyman, 1975). Trypsin, chymotrypsin or bile-pancreatic juice infused intestinally decreased the secretion of pancreatic enzymes. Diversion of bile-pancreatic juice from the intestine as well as intra-intestinal infusion of soybean trypsin inhibitor (SBTI) or protein stimulated the pancreatic enzyme output several fold. On the other hand, Corring (1974) has recently shown that diversion of pancreatic juice from the intestine in pigs caused an increase in pancreatic enzyme secretion. This high enzyme secretion was suppressed by returning the pancreatic juice to the intestine, but not by infusion of $\mathrm{NaCl}$ plus $\mathrm{NaHCO}_{3}$. Therefore, a pancreatic regulatory mechanism similar to that of the rat appears to exist in the pig. Similar results 
are obtained in humans (Laporte and Trémolières, 1973 ; Ihse, Lilja and Lundquist, 1977) but were not observed in dogs (Sale ef al., 1977).

To our knowledge, no such studies have been made on calves. Thus, the present investigation was undertaken to determine whether the proposed feed-back control of pancreatic enzyme secretion could be demonstrated in young calves.

\section{Materials and methods.}

Five male Holstein $\times$ Frisian calves, 45 days old and weighing $85 \pm 2 \mathrm{~kg}$, were used.

Surgery and sampling of pancreatic juice. The pancreatic duct of each animal had been chronically catheterized with a return cannula loop at the age of 10-12 days according to a technique previously described (Mc Cormick and Stewart, 1967 ; Davicco, 1978). Briefly, under halothan anesthesia and after isolation, $2 \mathrm{~mm}$ were longitudinally cut from the pancreatic duct near its duodenal opening. A polyvinylchloride catheter (external diameter $2.5 \mathrm{~mm}$; internal diameter $1.5 \mathrm{~mm}$ ) was inserted 10-12 $\mathrm{mm}$ into the pancreatic duct towards the pancreas; a similar catheter was firmly attached in the duct towards the intestine. The 2 catheters were connected outside by a rubber tube when pancreatic secretion was not being collected. Such a catheterization allowed us to infuse the pancreatic juice collection or another solution at the flow rate measured during sampling.

The calves were fed a milk replacer (Olivot-Sarb : $130 \mathrm{~g}$ powder $/ \mathrm{kg}$ water, $9 \mathrm{~kg} / \mathrm{animal} / \mathrm{day})$. During the first neonatal month, the mean daily weight gain of the animals was $990 \pm 250 \mathrm{~g}$.

Pancreatic juice was collected during 15 min periods in fubes kept at $4{ }^{\circ} \mathrm{C}$ in an ice-bath and its volume was measured. A $3 \mathrm{ml}$ fraction of each sampling was frozen for enzymatic and mineral analysis.

Infusion materials. In each animal, we have observed the influence of pancreatic juice, saline, trypsin (bovine pancreas, Serlabo, $2 \times$ crystallized, activity $=$ 10000 BAEE U. $\mathrm{mg}^{-1}$ proteins; $1.5 \mathrm{mg} \cdot \mathrm{ml}^{-1} \mathrm{NaCl} 0.9$ p. 100) and trypsin + SBTI (soybean trypsin inhibitor, Serlabo; $1 \mathrm{mg} \mathrm{SBTI}$ inhibits $1.7 \mathrm{mg}$ of trypsin), infused sequentially (fig. 1) at the duodenal level, on the composition of pancreatic juice collected during and after the infusion of each solution. Experiments started at the beginning of the afternoon ( 5 hrs after feeding). During the first 30 min of the experimental period, no pancreatic juice or solution was infused into the duodenum. Each solution, kept at $4{ }^{\circ} \mathrm{C}$ in an ice-bath, was infused into the duodenum over a 1-hr period, simulating the flow of pancreatic juice collected at the same time. The catheter being put in a water-bath $\left(38^{\circ} \mathrm{C}\right)$ during infusion, each solution reached the duodenum at body temperature.

Analysis. We measured the concentration of each thawed sample of pancreatic juice for total proteins, calcium, magnesium, zinc, inorganic phosphorus and amylase activity. The proteins were measured by Biuret's colorimetric reaction adapted to a Technicon autoanalyzer (Michel M. C., unpublished data). For the determination of amylase activity, we used a volume of pancreatic juice reacting with a starch solution 
for a given length of time in a water bath at $39{ }^{\circ} \mathrm{C}$. The sugars released after incubation were extracted by $85^{\circ}$ alcohol and measured by the sulphuric orcinol method (Besle, 1974). Calcium, magnesium and zinc were measured by atomic absorption spectrophotometry (Perkin Elmer 420). Inorganic phosphorus was determined by colorimetry (Michel, 1971).

In order to correct any infer-animal variations in pancreatic juice, the results were expressed as a percentage of those obtained during the hour before the first infusion. Thus each animal served as its own control and the significance of the differences between values was calculated by Student's $t$ test analysis.

\section{Results.}

When pancreatic juice was returned to the intestine at a rate similar to the collection rate of the preceding 15-min period, pancreatic juice flow, excretion of calcium, magnesium, inorganic phosphorus and zinc, and pancreatic amylase activity decreased significantly $(-60 \pm 10$ p. $100 ; P<0.05) 45 \mathrm{~min}$ after the infusion was started (fig. 1).

The introduction of 0.9 p. $100 \mathrm{NaCl}$ significantly increased $(P<0.05)$ the flow of pancreatic juice $(+100 \pm 30$ p. 100), excretion of calcium $(+30 \pm 10$ p. 100) and proteins $(+100 \pm 20$ p. 100), and amylase activity $(+100 \pm 25$ p. 100) (fig. 1).

One hour after saline infusion was stopped and bovine trypsin was introduced, pancreatic juice flow, calcium, magnesium, inorganic phosphorus, zinc $(-50 \pm$ 10 p. 100), proteins $(-80 \pm 5$ p. 100$)$ and amylase $(-70 \pm 15$ p. 100) significantly decreased (fig. 1).

When SBTI was given simultaneously with bovine trypsin the flow of pancreatic juice increased significantly $(+30 \pm 10$ p. $100 ; P<0.05)$, but we observed no significant effect on the excretion of calcium and proteins or on amylase activity (fig. 1).

\section{Discussion.}

Our results show that pancreatic juice or trypsin infused at the duodenum level in the calf decreases the pancreatic excretion of water, proteins and amylase, while intra-intestinal infusion of 0.9 p. $100 \mathrm{NaCl}$ or SBTI given simultaneously with trypsin leads to an immediate increase in the pancreatic excretion of water, proteins and amylase. Thus, these results indicate that pancreatic juice infused in the intestine of the calf may decrease pancreatic secretion (which then might be considered as physiological). They confirm data obtained in rats (Green and Lyman, 1972 ; Petersen and Grossman, 1977), pigs (Corring, 1974) and humans (Ihse, Lilja and Lundquist, 1977). Therefore, a pancreatic regulatory mechanism similar to that of rats, pigs and humans appears to exist in calves.

Recently Melmed, El-Aaser and Holt (1976) have shown in the rat that trypsin inhibitor feeding produces a definite increase in pancreatic enzyme synthesis, although Konijn, Birk and Guggenheim (1970) have demonstrated in vitro that while synthesis of trypsinogen and chymotrypsinogen is increased, amylase synthesis is reduced. But the mechanism by which trypsin suppresses pancreatic secretion remains obscure.

According to Laporte and Trémolières (1973), trypsin might act by way of blood 

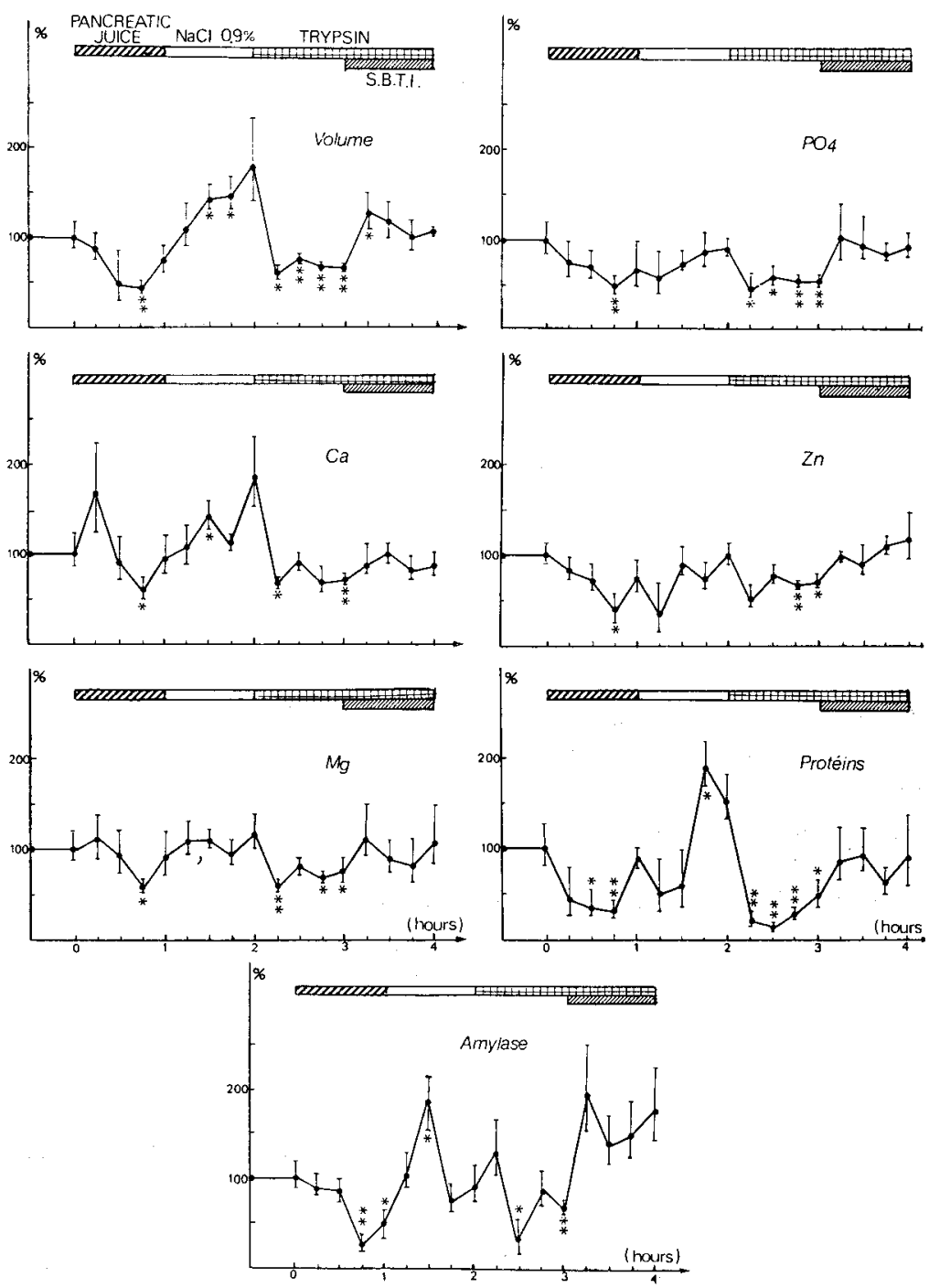

FIG. 1. - The effect of pancreatic juice, saline, trypsin and trypsin + soybean trypsin inhibitor (SBTI) infused in the duodenum on pancreatic juice flow rafe (volume) and on calcium (Ca), magnesium $(\mathrm{Mg})$, inorganic phosphorus $\left(\mathrm{PO}_{4}\right)$, zinc $(\mathrm{Zn})$, protein and amylase activity (amylase) pancreatic excretion in 5 calves (mode $\pm S$. E.). Results are expressed as the percentage of initial values obtained during the hour before the experimental period. ${ }^{*} \mathrm{P}<0.05 ;{ }^{*} \mathrm{P}<0.01$.

pathways after crossing the intestinal wall. This inhibition might be suppressed by trypsin inhibitors such as pancreozymin. Nevertheless, according to Corring (1974) and Schneeman and Lyman (1975), trypsin might act only at the duodenal level.

Indeed, when pancreatic juice in pigs was returned either to the level of the jejunum or the ileum, pancreatic secretion was not altered (Corring, 1974). Moreover, an intravenous infusion of trypsin (or SBTI or chymotrypsinogen) did not significantly 
alter the pancreatic juice output (Schneeman and Lyman, 1975). Thus trypsin inhibits pancreatic secretion only when infused in the uppermost third of the small gut where the cells responsible for the synthesis and release of cholecystokinin-pancreozymin (CCK-PZ) have been localized (Pearse, Polak and Bloom, 1977), and this effects is dose-dependent (Schneeman and Lyman, 1975). Therefore, trypsin (or chymotrypsin)sensitive receptors might control CCK-PZ release.

We have also demonstrated that in calves (Davicco, 1978) as in pigs (Corring, 1974), when pancreatic juice was returned to the duodenum, an intravenous infusion of secretin was able to stimulate exocrine pancreatic secretion, and that when pancreatic juice was not returned to the gut, the stimulation of the secretion could be mediated by endogenous secretin. Therefore, our results support the concept that trypsin might modulate pancreatic exocrine secretion by inhibiting the release of secretin.

In conclusion, a pancreatic regulatory mechanism similar to that demonstrated in rats and pigs appears to exist in young milk-fed calves. Such a regulation acts through a feed-back mechanism by enzymes (trypsin) excreted by the pancreas and released into the intestine.

Reçu en janvier 1979.

Accepté en avril 1979.

Acknowledgments. - The authors wish to thank A. Rérat and T. Corring for comments and reviewing the manuscript. This work was supported by the DGRST (ACC 75 7-0923) and by a grant from the Laboratoires Armour-Montagu.

Résumé. Cinq veaux mâles Holstein $\times$ Frisons, nourris avec un lait de remplacement, pesant $85 \pm 2 \mathrm{~kg}$ à l'âge de $45 \mathrm{j}$, porteurs d'un cathéter réentrant (implanté de façon chronique à l'âge de $10 \mathrm{j}$ ) sur le canal pancréatique ont été utilisés pour l'étude de l'influence de la réintroduction de suc pancréatique (ou d'autres substances) au niveau du duodénum sur la sécrétion pancréatique exocrine.

La réintroduction de suc pancréatique à un débit identique à celui mesuré pendant les $15 \mathrm{mn}$ précédentes entraîne dans les $45 \mathrm{mn}$ qui suivent une diminution significative (-60 \pm 10 p. 100) du débit pancréatique, de l'excrétion des minéraux ( $\mathrm{Ca}, \mathrm{Mg}, \mathrm{P}, \mathrm{Zn})$ et de l'amylase.

La réintroduction d'une solution aqueuse de $\mathrm{NaCl}(0,9 \mathrm{p}, 100)$ consécutive à celle du suc pancréatique, entraîne une augmentation significative du débit ( $+100 \pm 30$ p. 100), de l'excrétion de calcium $(+30 \pm 10$ p. 100), de protéines $(+100 \pm 20$ p. 100) et de l'amylase $(+100 \pm 25$ p. 100).

Le remplacement de sérum physiologique par une solution de trypsine bovine $\left(1,5 \mathrm{mg} \cdot \mathrm{ml}^{-1}\right.$ dans $\mathrm{NaCl} 0,9$ p. 100) provoque une inhibition significative de l'excrétion d'eau, des minéraux $(-50 \pm 10$ p. 100), des protéines $(-80 \pm 5$ p. 100) et d'amylase $(-70 \pm 15$ p. 100).

L'addition d'un inhibiteur de trypsine SBTI (1 mg SBTI inhibe 1,7 mg de trypsine) à la solution de trypsine réintroduite stimule significativement $(+30 \pm 10$ p. 100) le débit pancréatique.

\section{Références}

BESLE J. M., 1974. Séparation des oses, des di- et triholosides par chromatographie d'échange d'ions. Ann. Biol. onim. Bioch. Biophys., 14, 545-573.

CORRING T., 1974. Régulation de la sécrétion pancréatique par rétro-action négative chez le porc. Ann. Biol. anim. Bioch. Biophys., 14, 487-498. 
DAVICCO M. J., 1978. Régulation du pancréas exocrine du jeune veau. Thèse Doct. Spécial. Univ. Clermont II, no 542. 102 pp.

GREEN G. M., LYMAN R. L., 1972. Feedback regulation of pancreatic enzyme secretion as a mechanism for trypsin inhibitor induced hypersecretion in rats. Proc. Soc. exp. Biol. Med., 140, 6-12.

GREEN G. M., OLDS B. A., MATTHEWS G., LYMAN R. L., 1973. Protein, as a regulator of pancreatic enzyme secretion in the rat. Proc. Soc. exp. Biol. Med., 142, 1162-1167.

HARPER A. A., 1972. Progress report. The control of pancreatic secretion. Gut, 13, 308-317.

IHSE I., LILJA P., LUNDQUIST I., 1977. Feedback regulation of pancreatic enzyme secretion by intestinal trypsin in man. Digestion, 15, 303-308.

KONIJN A. M., BIRK Y., GUGGENHEIM K., 1970. In vitro synthesis of pancreatic enzymes : effects of soybean trypsin inhibitor. Am. J, Physiol., 218, 1113-1117.

LAPORTE J. C., TRÉMOLIĖRES J., 1973. Action de la trypsine et des inhibiteurs trypsiques sur la sécréfion pancréatique. Nutr. Metabol., 15, 192-206.

MCCORMICK R. J., STEWART W. E., 1967. Pancreatic secretion on the bovine calf. J. Dairy Sci., 50, 568-571.

MELMED R. N., EL-AASER A. A. A., HOLT S. J., 1976. Hypertrophy and hyperplasia of the neonatal rat exocrine pancreas induced by orally administered soybean trypsin inhibitor. Bioch. biophys. Acta, 421, 280-288.

MICHEL M. C., 1971. Analyse quantifative de quelques substances azotées ef glucidiques en milieu biologique. Essai de rationalisation. Thèse Doct. Univ., Clermont-Ferrand, $\mathrm{n}^{\circ} 43$.

PEARSE A. G. E., POLAK J. M., BLOOM S. R., 1977. Progress in gastroenterology. The newer gut hormones. Cellular sources, physiology, pathology and elinical aspects. Gastroenterology, 72, 746-761.

PETERSEN H., GROSSMAN M. I., 1977. Pancreatic exocrine secretion in anesthetized and conscious rats. Am. J. Physiol., 233, E 530-E 536.

SALE J. K., GOLDBERG D. M., FAWCETT A. N., WORMSLEY K. G., 1977. Chronic and acute studies indicating absence of exocrine pancreatic feedback inhibition in dogs. Digestion, 15, 540-555.

SCHNEEMAN B. O., LYMAN R. L., 1975. Factors involved in the intestinal feedback regulation of pancreatic enzyme secretion in the rat. Proc. Soc. exp. Biol. Med., 148, 897-903.

THOMAS J. E., 1967. Neural regulation of pancreatic secretion. In : Handbook of Physiology. Section 6, 2, 955-968. Amer. Physiol. Soc., Williams and Wilkins Co. 